Vaganova L. $V$.

Ph. D. in Economics, Associate Professor, Department of Economics and Management, Khmelnytsky Institute for the Name of His Beatitude, Metropolitan of Kyiv and All Ukraine of PJSC “HEI "IAPM” Interregional Academy of Personnel Management, Ukraine ; e-mail: milascincevaganova@gmail.com; ORCID ID: 0000-0002-5812-4597

Chaikovska I. I.

Ph. D. in Economics, Associate Professor, Department of Mathematics, Statistics and Information, Technologies Khmelnytsky University of Management and Law, Ukrain; e-mail: inna.chaikovska@univer.km.ua; ORCID ID: 0000-0001-7482-1010

Khrushch N. A.

Doctor of Economics, Professor, Head of the Department of Finance, Banking and Insurance Khmelnytsky National University, Ukraine; e-mail: nila.ukr@gmail.com; ORCIDID:0000-0002-9930-7023

Hryhoruk P. M. Doctor of Economics, Professor, Head of the Department of Automated Systems and Modeling in Economics, Khmelnytsky National University, Ukraine; e-mail:hryhoruk@khnu.km.ua; ORCIDID:0000-0002-2732-5038

\title{
NETWORK STRUCTURE AS TOOL FOR DEVELOPING INFORMATION NETWORK ECONOMY
}

Abstract. This article is devoted to the process of establishing a network' structures and their management, which based on the different methodological approaches. The modern development of economic relations are closely connected with the changing of market relations and economic orientation of the enterprise, it affected at the development of network entities. The interest of scientific community to the processes of networking organizations was caused by the deepening of integration processes and using of various forms of inter-firm interaction. According to the analysis of the professional literature, it was installed that there were no attempts to substantiate the essential functioning of characteristics and the process of phenomenon of the network economy. Effective management of network structures based on use the relationship between the features of the network economy and the process of phenomenalization of this economy. The statement of basic materials: interpretation of scientific views and the definition of "network economy"; logic in the network economy; the investigation aбo study of the formation, development and functioning of the network economy; discovery (education) the phenomenon of the network economy. Conclusions: formed a general idea about the network structure; described the interconnection of functioning the essential characteristics and phenomenal network economy; the use an arsenal of methodological approaches secured the effective management of network structures.

Keywords: network structure, network economics, methodological approaches, phenomenon creating.

GEL Classification: B5

Formulas: 0, fig.: 1; tabl.: 0; bibl.: 10 .

Ваганова Л. В.

к.е.н., доиент кафедри економіки та управління, Хмельнищький інститут імені Блаженнішого Володимира, Митрополита Київського і всієї Украӥни ПАТ “ВНЗ “МАУП”, Украӥна; e-mail: milascincevaganova@gmail.com; ORCID ID:0000-0002-5812-4597 
Чайковська I. I.

к.е.н., доиент кафедри математики, статистики та інформаџійних технологій,

Хмельницький університет управління та права, Україна; e-mail: inna.chaikovska@univer.km.ua; ORCID ID: 0000-0001-7482-1010

Хрущ Н. $А$.

д.е.н., професор, завідувач кафедри фінансів, банківської справи і страхування,

Хмельницький начіональний університет, Украӥна; e-mail: nila.ukr@gmail.com; ORCID ID:0000-0002-9930-7023

Григорук П. М.

д.е.н., професор, завідувач кафедри автоматизованих систем і моделювання в економіці,

Хмельницький національний університет, Украйна; e-mail:hryhoruk@khnu.km.ua; ORCIDID:0000-0002-2732-5038

\section{МЕРЕЖЕВА СТРУКТУРА ЯК ІНСТРУМЕНТ РОЗВИТКУ ІНФОРМАЦІЙНО-МЕРЕЖЕВОЇ ЕКОНОМІКИ}

Анотація. Основною ціллю статті є обгрунтування взаємозв'язку функціонування сутнісних характеристик та феноменалізації мережевої економіки 3 метою забезпечення ефективного управління мережевими структурами на основі використання арсеналу методичних підходів. У роботі сформовано загальне уявлення про мережеві структури; обгрунтовано взаємозв'язок функціонування сутнісних характеристик та феноменалізації мережевої економіки; забезпечено управління мережевими структурами на основі використання арсеналу методичних підходів.

Ключові слова: мережева структура, мережева економіка, методичні підходи, феноменалізація.

Формул: 0; рис.: 1; табл.: 0; бібл.: 10.

Ваганова Л. В.

к.э.н., доцент кафедры экономики и управления, Хмельницкий институт имени Блаженнейшего Владимира, Митрополита Киевского и всея Украины ПАО "ВУЗ" МАУП", Украина; e-mail: milascincevaganova@gmail.com; ORCID ID: 0000-0002-5812-4597

Чайковская И. И. к.э.н., доцент кафедры математики, статистики и информационных технологий,

Хмельницкий университет управления и права, Украина; e-mail: inna.chaikovska@univer.km.ua; ORCID ID: 0000-0001-7482-1010

Хрущ Н. $А$. д.э.н., профессор, заведующий кафедрой финансов, банковского дела и страхования, Хмельницкий национальный университет, Украина; e-mail:nila.ukr@gmail.com; ORCIDID:0000-0002-9930-7023

Григорук П. Н.

д.э.н., профессор, заведующий кафедрой автоматизированных систем и моделирования в экономике,

Хмельницкий начиональный университет, Украина; e-mail: hryhoruk@khnu.km.ua; ORCIDID:0000-0002-2732-5038

\section{СЕТЕВАЯ СТРУКТУРА КАК ИНСТРУМЕНТ РАЗВИТИЯ ИНФОРМАЦИОННО-СЕТЕВОЙ ЭКОНОМИКИ}

Аннотация. Основной идеей статьи является обоснование взаимосвязи функционирования сущностных характеристик и феноменализации сетевой экономики с целью обеспечения эффективного управления сетевыми структурами на основе использования арсенала методических подходов. В работе сформировано общее представление о сетевых структурах; обоснованно взаимосвязь функционирования 
сущностных характеристик и феноменализации сетевой экономики; обеспечено управление сетевыми структурами на основе использования арсенала методических подходов.

Ключевые слова: сетевая структура, сетевая экономика, методические подходы, феноменализация.

Формул: 0; рис.: 1; табл.: 0; библ.: 10.

Introduction. Characteristic conditions of the modern state of economic relations are changing market strategies and economic orientation of firms in some way affected the development of network structures.

Analysis of the studies found significant attention to scientists to network structures. So, scholars often identify the network structure of the clusters, franchising, outsourcing of production, alliances and holdings. Obviously, all of these concepts are interlinked, but here it's just about forms and methods of network organizational structures manifestation in the market environment. Also in the scientific literature have attempted to study the functioning of the essential characteristics and the process of phenomenon creating network economy. It shows lack of public understanding about the network structure as a result of the relationship with the network economy, i.e. the internal mechanism of the socio-economic system.

Actual scientific researches and issues analysis. The research of problems installing network economy held in their treatises such foreign and domestic scholars: V. M. Matyushok, S.A. Dyatlov, M. Castels, R. Vayber, L. M. Katz, J. Farrell, G. Saloner, T. Veytsel, O. Wendt, F. Westarp, B. De Lang, M. Frumkin. A study of the practice of marginal interaction organizations appearing in the work of the following researchers: G. Norman, G. Ramirez, G. Coase, G. Garella, R. Milles, C. Snow, J. Mathews, H. Coleman.

The research objective is the ground of relationship essential characteristics functioning and phenomenon creating the network economy in order to ensure effective management of network structures using the arsenal of methodological approaches.

The statement of basic materials. The modern state of the network economy, which started with the 1969 year is the result of a rapid and efficient development of information and communication technologies. Some researchers attributed the genesis of the concept of "network economy" with category information society that originated in Japan over the 1960-1970s, and subsequently a more specified by American and British scientists.

In particular, the definition of the term "information society" belongs to a Professor, Tokyo Institute of Technology Y. Hayashi. The term "network economy" is often identified with the "global economy" [1]. About the information revolution, information society, information economy began to reminisce in 70-those of the XX century, in particular E. Tofler, G. Drucker. Modern research in the development of global information and communication technology resulted in the formation of global electronic environment for economic activity.

The most important conditions of network economy formation include, above all, formation in the 1980-1990s fifth technological life. The leading position among the most powerful multinational companies occupy Corporation "Microsoft", "Intel", where the main development strategies are expansion of creative activity, creation of conditions for improvement of the person within her professional activity, development of creative abilities.

The famous researcher of information society M. Castels noted that the emergence of the economy with a network structure and the profound interdependence of elements allows for its achievement in technology, knowledge and management as a technology and knowledge, and thus control. The combination of the mentioned components will achieve greater productivity and efficiency in the presence of the necessary conditions for the equally profound organizational and institutional changes [2].

The German researcher R. Vayber points out that the information base innovation, should be considered as the basis for economic growth, and digital and computer techniques as the core innovation under the title information technology" [3]. The researcher examines information technology from the point of view of the source of the economic development momentum and special instrumental takes the form of network structures. This largely affects the promotion of the network economy and the emergence of new economic forms. 
Modern researchers are united in the belief that the sign of a network economy is the presence of network externalities (direct effects associated with the increase in the value of the product with the growth in the number of its users; indirect effects associated with the development of complementary markets) and additional benefits.

Independent conceptual approach regarding the interpretation of the network economy serving a cluster of neoclassical models. They view the actions of each agent, as a function of time in which the action takes place, and the information has an agent. In fact, similar models reject the concept of complete rationality behavior of agents and investigate individuals who are able to develop, and evolutionary systems in general. In accordance with the overall result of the greater part of built models are Pareto-optimum results of process standardization, despite the fact that empirical data refute this fact. In particular, T. Veytsel, O. Wendt, F. Westarp believe that this is the result of the assumptions on which it is based classical and neoclassical theory. Scientists point to the need to build a model that could unite the methodological aspects of both approaches. They put forward the following requirements for this model [4]: 1) modeling of knowledge and uncertainty, limited rationality; 2) examination of the evolutionary dynamic system; 3) branching networks, which should take into account the possibility of splitting the network or even her disappearance; 4) taking into account the indivisibility of goods and services; 5) consideration of social interaction between users of a given good.

In turn the formation of organizational-economic and socio-economic relations, has contributed to the emergence of a new economic form order and the network forms formation and organization at different levels of the economy. The network economy is different from the economy, where the inherent market and hierarchical form, thanks to such features as: exceptionation - the ability of sellers get consumers to become buyers; the rivalry - the presence of manufacturers that produce the same operation with different costs; transparency - understanding individuals of their needs and their satisfaction.

Having the basic principles of the market system functioning, it is necessary to reach the conclusion that organization' network form of interaction can: reduce the need for hierarchical managerial structures (without clearing which today it was impossible to organize joint work a large number of people); change the social status of the economic relations' participants (since it ceases to be the decisive factor that determines their behavior); increase the speed of solving all issues (in this case the costs of getting results is not growing, and greatly reduced).

In the course of evolutionary studies scientific' views on the network structure organization' phenomenon in economic theory, we have determined the interconnectical functioning of the essential characteristics and phenomenon creating network economy Fig. 1.

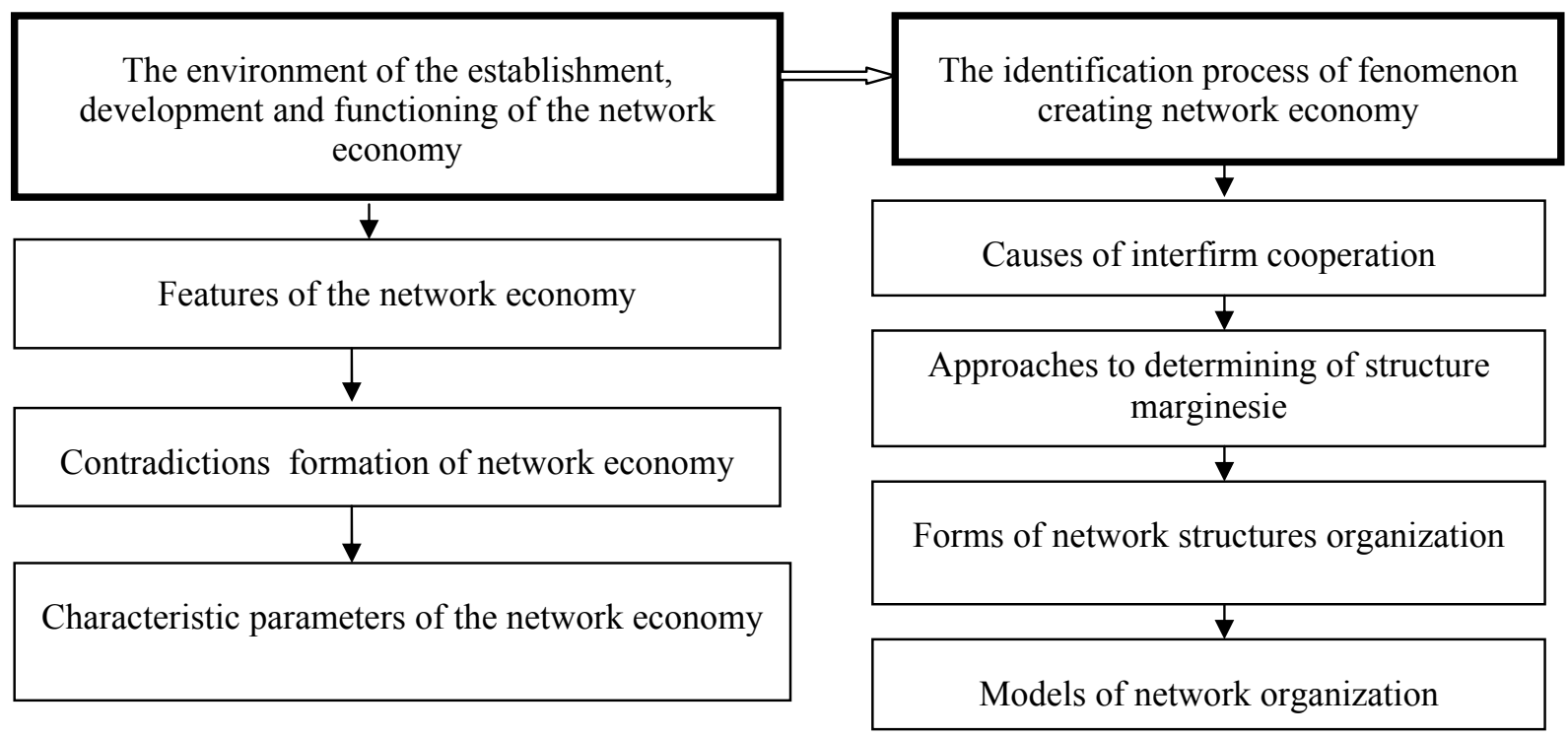

Figure 1. - Relationship of the essential characteristics functioning and fenomenon creating network economy Authoring 
Important features of network economy are the following: 1) availability of global electronic environment for economic activities, the exchange of information, knowledge, ideas and active use of information technologies; 2) in a networked economy, the value of the labor stems products from their plurality; 3) the basic law the functioning of networks known as the law of increasing returns.

In terms of the network economy is increasing the degree of entropy economic space. In addition the basis of network economy formation lies as benefits and controversies, first connected with the latest features Fig. 1. In particular preferred specialization and concentration on key competences, which contradicts the current multifaceted skills orientation of the network participants. The results of professional scientific literature analysis [5 and others] are the main parameters of the network economy (Fig. 1.), in particular: 1) element of the system can be displayed in the form of e-business, e-money (banks), the producers and consumers of goods (the participants of the network), the network market; 2) criteria of a functioning, which are reduced to save time and efficiency informational interaction; 3) target as a positive development the overall economic system; 4) the task that shows the speed and quality of informational interaction in the economic activity of entities in order to ensure economic growth; 5) form is continuously variable and dependent on the development state of its enclosure filling and not dependent on the model of the economic system in which it operates; 6) substantial content as a set of components (at some level); 6) feedback occurs based onasignals of supply and demand; 7) borulce external environment (macroeconomic system national or supranational level), which operates a network economy becomes cheaper.

The benefits of functioning in inter-firm networks will certainly create the motivation for integration of various enterprises. A study of the practice margins network interactions of organizations shows that one of the main reasons of its appearance is a necessity for the formation of more adequate to the needs of a modern system of creating consumer value. It is worth noting that over the past decade have taken place fundamental changes in the way the formation of consumer value. G. Norman, G. Ramirez believe that the modern consumer value has become more "eventful". They understand the "saturation" as a measure of information, knowledge and other resources quantity. [6]. The system of creating consumer value in inter-firm networks can be seen as a set of specific activities. Its members carry out, relying on the resources they own, the skills, knowledge and abilities, including updating and development. Creation of network interaction enabled through the use of the complementary resources of partners to achieve the strategic goals that are unattainable for individual members, and provide economic growth.

Important driving the cause of network cooperation companies rightly considered the creation of additional opportunities for savings in all kinds of expenses. The special attention of scientists drawn to the study of the reducing possibilities the first transaction costs [7].

Despite the presence of a significant research' amount on the functioning of the enterprises inter-firm networks in the global and domestic theory and practice has simplicity in the sense of the term. The range of differentiation lies in the range from informal formations that feature oral agreements, to the formation of enough centralized structures based on vertical integration. The founders of the approach, according to which the network structure was first recognized as an organizational decision, considered by R. Milles, C. Snow, J. Mathews, H. Coleman. In the 80 years of the twentieth century, they have studied the practice of numerous companies and concluded. Inter-firm networks are a new milestone in the evolution of organizational structures: linear function - divisional - matrix - network. Feature of network structures as temporary formations. They coordinate their activities on the basis of trust and sharing information, and in the management of network structures dominated by market mechanisms, on the basis of them used the collective assets of various entities serving different areas of the consumer chain values [8].

Significant contribution to the understanding of inter-firm networks phenomenon of interaction was made in marketing research. In the middle of the 1970-years of the twentieth century, a team of scientists from Europe have established the international society of Industrial Marketing and Purchasing Group. Since the beginning of its Foundation this company actively vindicated idea about the role of relationships in explaining the behavior of organizations. The first 
large-scale study of this collective was the analysis of industrial relations in the supply chains of European companies.

As a result, scientists concluded that in today's economy, the emphasis should be on building the client management model based on the network of relations. Thus was launched a new research platform-relationship marketing. The emphasis is on strategy, supplier management, internal marketing, relationships in the distribution channels, forms and methods of communication with end consumers. As a result members of the business network get effects such as: reducing the cost of basic activities and costs associated with the influence of market factors, the growth of turnover and market share, reduced output cycles on the market of new products, as well as the creation of new value for consumers.

The network approach empowers marketing relationships from the perspective of achieving the synergistic effect of the activity of the business structures. Business relationships with suppliers and competitors in business network can be viewed in different angles: relations between the organizations, technology and other economic phenomenon; cooperation, partnership and mutual support; the mutual conditionality and the influence of entities at each other on the network in general, and economic systems of the upper levels; forms of influence on management, changing their conditions, the achievement of the general and private purposes; the exchange process. In accordance with the network cooperation and integration of the business contributed to the emergence of a technology franchise.

Intensification of entrepreneurial activity contributes to the emergence of new forms of inter-organizational relationships, including entrepreneurial networks - the cluster approach based on existing knowledge formed the institutional infrastructure for economic growth [9]. The principal provisions of the cluster approach, which bring economic benefit to the development of institutions and enterprises, are: 1) the reduction and elimination of industry, market barriers; 2) "economies of scale" to reduce the cost of business activity; 3) prerequisite to integration organizations commercial, non-profit and public sectors; 4) integrated support for entrepreneurial initiatives and inter-claster competition; 5) reducing the time from the birth of the idea to the beginning of its implementation, as well as the time required for the implementation and dissemination of innovations; 6) building effective relationships with partners and contractors; 7) acceleration of resources exchange, including intelligent.

Conceptually new is theoretical-game approach that anticipates that the decision of each participant in any sphere of influence on the participants and their solutions rest. Every company should evaluate chain reactions and determine a way for optimal decision making. Moreover, the various players within the same industry can interact in such a way that economic results of each will only intensify. These postulates and planned analysis of the networks. In general, business activity is considered as a game in the sense that the actions of one of the participants in the business affect the profitability of others. Decisions in business are accepted on the basis of the analysis of possible number of outcomes, when each of them is how to react to other participants in the industry.

In recent years, the application of the game theory greatly increased and acquired a new direction. Participants of the game can change its potential results, by changing the structure of the industry in one of several ways. A. Brandenburger [10] offers corporations use method of PARTS based on certain "incorporates" the influence to change the structure of the industry. The corporation may threaten to change the number of players (participants) in the field (P - Players), announcing his intention to enter into the business in this area. A simple threat entails receiving compensation. This will lead to a change in the distribution of the pay table (added value) among industry participants. The corporation may change the value added (A - Added value) by reducing the value of the other or by increasing its own. The corporation may change the rules of the game ( $\mathrm{R}$ - Rules), by, for example, the new pricing policy. In addition, the corporation may change the tactics ( $\mathrm{T}$ - Tactics) so that it will change the perception of the other players, and there by affect their decisions. The corporation can also change the scope of the game (the letter S-Scope). This is happening by breaking its ties with other players or build new alliances. 
Generalising approaches to the study of networks, it is necessary to mention two main approaches of economic-theoretical and managerial. The difference between them is the following: interests of specialists with management boils down to our description of the network organization phenomenon from the perspective of change processes, structures, boundaries, new rules of governance. For managers, what is important is the principle of network interaction regardless or its management nutriv network, franchise network or virtual organizations. In its black economictheoretical approach focuses on the comparative effectiveness and efficiency of different methods of coordination, the competitive advantages and rent, which are available to the participants. In economic theory are problems such as the comparison of integration and disintegration categories, the allocation of "pure" networks types and their varieties, comparing different alternatives in terms of costs, etc. It is worth noting that the scientific papers of most scholars leveling selection indicated approaches in its purest form. So, X. Hokanson, I. Johansson, M. Forsgren in the analysis of industrial networks based on their social definition. They analyse the alternative governance structure from the perspective of internal and external interests.

Most scientific papers devoted to the analysis of networks on the basis of literature. It promotes the excretion of general features and problems, as well as consensus in matters, which generates the network way of organizing. However, it kept the need to select each of the theoretical platform that will be taken as a basis.

Based on the results of research conducted with the genesis economic thought and agreeing with the opinion of the game theory approach supporters and based on the synthesis of existing interpretations under the definition of the network organization content to understand the following: is the economic category, which is a manifestation of significant social processes for the establishment, development and operation of the network economy. It includes a set of business solutions interested participants not linked administrative relations. Their goal is to create the consumer value of end products based on the search features to minimize the cost of operating activities and effective ways to reduce uncertainty in the environment of international business.

Management of experience organizations in the economic theory indicates that there is a separate form of network structures organization: network, formed around a big company; the network of companies that close in scope; virtual company; clusters, etc. (Fig. 1). In connection with the transition to an information economy and in the conditions of globalization are quoted form of organization' network structures are characterized by a change in the type of enterprise from vertical bureaucratic to of horizontal network. It is a unified management team, flat hierarchy, the measurement results of the satisfaction level, etc.

The appeal of business network forms due to very high production indexes that are attributable to two factors, namely the competence and effectiveness of the organizational network. The effectiveness of the network' organizations is guaranteed by the low level of employment and rational structure. The network excluded the possibility of competent workforce duplication and facilities at various sites. Thus, it is possible to avoid the high total cost of production or an inhouse exchange service. In turn, the international experience indicates that there are three models of the network organization (Fig. 1), in particular: the union in the form of network organization legally independent structures, mainly in the form of franchising; the union in the form of network organization legally separate structures, mainly in the form of franchising; the union around the company, which occupies a leading position on the local consumer market, small commercial enterprises that operate in this market segment; enterprises of trade enterprises under a single control and jurisdiction. This is to reduce the cost of doing business and increase competitiveness through new properties and relationships created by the network structures.

Conclusions. The results of the scientific views analysis concerning revelation and establishment of the network structure phenomenon' organization in economic theory contributed to: 1) formation of a general idea about the network structure as a result of the internal mechanism of the socio-economic system relationship in the network economy form; 2) explanation of the relationship of the essential characteristics functioning and fenomenon creating network economy; 3) ensuring effective management of network structures on the basis of methodological approaches arsenal. 


\section{Література}

1. Матюшок В. М. Сетевая экономика и глобализация экономической деятельности / В. М. Матюшок // Информационное общество. - 1999. - Вып. 6. - С. 46-47.

2. Castels M. The information age: economy, society and culture / Castels M. - Oxford : Blackwell Publishers, 1996-1998. Vol. 1, 2. - Russian translation ed. by O. Shkaratan. - Moscow : GU-VshE., 2000.

3. Vayber R. Empirical laws of the network economy / R. Vayber // Reference Problems of management theory and practice. 2003. - Vol. 3. - P. 82-88.

4. Veytsel T. Reconsidering network effect theory. Library Review [Electronic Resource] / T. Veytsel, O. Wendt, F. Westarp. Available from : http://www.wi-frankfurt.de/publikationen/ publikation143.pdf.

5. Авдошин С. М. Синергетические организации в экономике XXI века / С. М. Авдошин, В. Б. Тарасов. - Москва : Бизнес-информатика, 2006. - Т. 17. - С. 164.

6. Baldwin C. Construction of the value chain / C. Baldwin, B. Klim Clark, J. Magretta [and others] ; ed. D. Fites. - Moscow : OOO «United Press», 2009. - P. 246.

7. Пожидаев Р. Координирующая роль межфирменных сетей: концепции и направления исследований / Р. Пожидаев // Вестник Воронежского государственного университета. - 2012. - № 1. - С. 120-129. - (Серия : Экономика и управление).

8. Milles R. Organizing in the knowledge area: anticipating the cellular form Academy of Management Executive / R. Milles, C. Snow, J. Mathews, H. Coleman // Academy of Management Executive, 1997. - Vol. 11, No. 4. - P. 7-24.

9. Николаев М. Стратегия повышения конкурентоспособности алмазного комплекса России [Электронный ресурс] / M. Николаев, А. Марактаев // Проблемы современной экономики. - Режим доступа : http:/www.meconomy.ru/art.php?nArtId=879.

10. Brandenburger A. M. The right game: use game theory to shape strategy / A. M. Brandenburger, B. J. Nalebuff // Harvard Business Review. - 1995. - P. 246.

Стаття надійшла до редакиії 25.09.2017

(СВаганова Л. В., Чайковська I. I., Хрущ Н. А., Григорук П. М.

\section{References}

1. Matyushok, V. M. (1999). Setevaya ehkonomika i globalizaciya ehkonomicheskoj deyatel'nosti [Network economy and globalization of economic activity]. Informacionnoe obshchestvo - Information society, 6, 46-47 [in Russian].

2. Castels, M. (2000). The information age: economy, society and culture. Oxford: Blackwell Publishers, 1996-1998. (Vols. 12). (Rus. trans. ed. by O. Shkaratan). Moscow: GU-VshE.

3. Vayber, R. (2003). Empirical laws of the network economy. Reference Problems of management theory and practice, $3,82-88$.

4. Veytsel, T., Wendt, O., \& Westarp, F. (2000). Reconsidering network effect theory. Library Review. Retrieved from http://www.wi-frankfurt.de/publikationen/ publikation143.pdf.

5. Avdoshin, S. M., \& Tarasov, V. B. (2006). Sinergeticheskie organizatsii v ekonomike XXI-go veka [Synergetic organizations in the economy of the 21st century]. Moscow: Biznes-informatika [in Russian].

6. Baldwin, C., Klim, C., Magretta B., Dyer J., Fisher J., Fites M., D. (2009). Construction of the value chain. Moscow: OOO «United Press», 246.

7. Pozhidaev, R. (2012). Koordiniruyushchaya rol' mezhfirmennyh setej: koncepcii i napravleniya issledovanij [Coordinating role of inter-firm networks: concepts and directions of research]. Vestnik Voronezhskogo gosudarstvennogo universiteta - Bulletin of Voronezh State University, 1, 120-129 [in Russian].

8. Milles, R., Snow, C., Mathews, J., \& Coleman, H. (1997). Organizing in the knowledge area: anticipating the cellular form Academy of Management Executive. Academy of Management Executive, 11 (4), 7-24.

9. Nikolaev, M., \& Maraktaev, A. (2017). Strategiya povysheniya konkurentosposobnosti almaznogo kompleksa Rossii [Strategy of increasing the competitiveness of the diamond complex in Russia]. Problemy sovremennoj ehkonomiki - Problems of modern economics. Retrieved from http:/www.m-economy.ru/art.php?nArtId=879 [in Russian].

10. Brandenburger, A. M., \& Nalebuff, B. J. (1995). The right game: use game theory to shape strategy. Harvard Business Review.

Received 25.09.2017

(CVaganova L. V., Chaikovska I. I., Khrushch N. A., Hryhoruk P. M. 